\title{
Panagiotis Pavlos
}

\section{Christian insights into Plotinus' Metaphysics

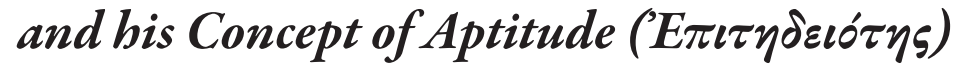

Abstract: Modern scholarship on Late Antique philosophy seems to be more interested than ever before in examining in depth convergences and divergences between Platonism and Early Christian thought. Plotinus is a key figure in such an examination. This paper proposes a preliminary study of the Plotinian concept of aptitude, as it emerges throughout the Enneads and aims at shedding light to certain aspects of Plotinian metaphysics that bring Plotinus into dialogue with the thought of Church fathers by means either of similarities or differences between Neoplatonist and Christian thought. It will be argued that the concept of aptitude is crucial as it involves the relation between the One and the many, the reality of participation, the relation of the cosmos with, and its dependence on, the superior spheres of being, the bestowal of divine gifts upon beings, and the possibility of the deification of the human being.

Keywords: Aptitude, Christianity, consubstantiality, creation, deification, emanation, hierarchy, metaphysics, Neoplatonism, participation.

\section{Introduction}


cosmos has generally been acknowledged by the scholarly world. But the concept has not benefited from anything more than a sporadic treatment. This is striking, given

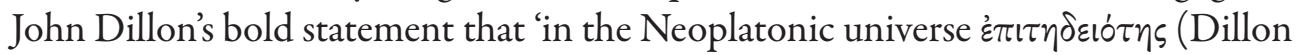
uses the term receptivity) is all.' Indeed, the primary sources contain a plethora of evidence on the concept. This evidence shows how well aptitude is integrated into the philosophical representation of the cosmos in Late Antiquity. Consequently, one

*Department of Philosophy, University of Oslo, panagiotis.pavlos@ifikk.uio.no

${ }^{1}$ Glen R. Morrow and John M. Dillon (eds.), Proclus' Commentary on Plato's Parmenides, Princeton: Princeton University Press, 1987, 13. The literature seems to present no consensus in rendering the term epitédeiotes. There appear several renditions, such as fitness, capacity, receptivity, suitability, appropriateness, adaptability and aptitude. For reasons that I discuss elsewhere, I find most

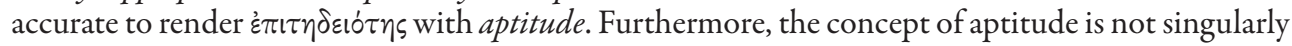
designated by the term epitédeiotes. One may be aware of the presence in the sources and the use, as a matter of fact, of a group of terms that either express the very notion of aptitude in alternative ways or point to notions kin to it. A cluster of concepts that are familially connected with aptitude would

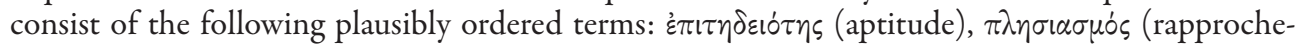

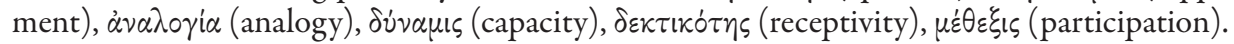


might expect to find aptitude widely discussed in the relevant secondary studies. The reality, however, seems to be quite different. For in contrast to the reputed centrality of the concept, very little has been written on it. The lack of adequate study is remarkable, if one considers the central questions of Plotinian Neoplatonic metaphysics that this intricate concept involves: a) the relation between the One and the many; b) the reality of participation; c) the relation of the cosmos with, and its dependence on, the superior spheres of being; d) the bestowal of divine gifts upon beings that are lower in rank; and e) the possibility of the deification of the human be-

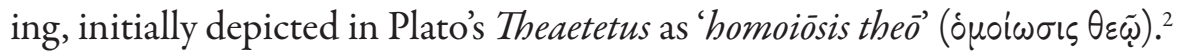

In addition to this network of central issues, one should consider a cluster of topics that either derive from the above, emerging equally in Neoplatonic metaphysics and Christian thought, or else are found in distinctively alternative ways in the philosophical writings of Church fathers. Such a cluster would contain: a) the question of becoming, both in its emanationist and creationist aspect; b) the possibility and the reality of receiving and understanding what lies beyond the given status of beings and uniting with it by 'henōsis' ( object of erōs (" $\tilde{p} \omega \omega \varsigma$, love), this 'beyond' itself remains paradoxically totally veiled, unknown and unknowable; and c) the reception of grace that allows for deification, the latter conceived neither as the end of intellectual inquiry and the final release of the soul from the malevolent bondage of the body nor as a fusion with divine essence, but as a graced participation that includes the whole man, as soul-body compound, in the life of divinity manifested in the divine power and activity.

In his classic three-volume work on ancient paideia, Werner Jaeger offers a thorough study of the history of Greek philosophical culture and thought from its origins to its latest and greatest moments. ${ }^{3}$ Bishop Athanasios Jevtić, in reconstructing Jaeger's account says the following: 'at a certain point, when Jaeger reaches the philosophical state of affairs of 3rd century AD and especially the thought of Plotinus, he poses the following question: what happened to all this enormously great philosophical stream and impulse that after Plotinus disappeared, suddenly as it were'? Jevtić notes that Plotinus maintained this stream in its peak. He goes on to add that after Plotinus one would search almost in vain to find any great Greek thinkers. Jevtić makes an even more challenging claim in saying that 'the few Greek philosophers, such as Iamblichus, Proclus and Damascius are only minor figures',

2 Plato, Theaet. $176 \mathrm{ab}$.

${ }^{3}$ Werner Jaeger, Paideia. The Ideals of Greek Culture, vol. I, Gilbert Highet (transl.), New York: Oxford University Press, 1965.

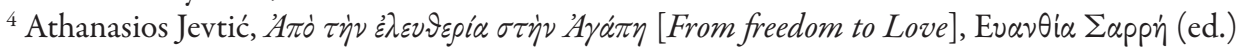
[in Greek], Athens: Domos, 2012, 151-152. Translation from the Greek original inserted by me. 
and that 'Greek philosophy ceases to exist by the times of the emperor Justinian and the forced suspension of the School of Athens.'

Despite the fact that this claim regarding the decline of Greek philosophy would immediately provoke many scholars who would hastily raise harsh objections against it, a significant point is made here. Plotinus is acknowledged as the last great Greek philosopher. I think that Jevtićs remark is correct. For Plotinus was the thinker who synthetized in a novel and inclusive account the central ideas of the Presocratics, of Plato and the earlier Platonists, of Aristotle, of the Stoics and of the Peripatetics. ${ }^{6}$ His thought exercised a great influence on later philosophy. Hilary Armstrong judges that Plotinus 'did not dominate the thought of his time or entirely determine the later development of Platonism.' But although Armstrong would rightly deny that Plotinus was the founder of Neoplatonism, since he did not found a school, looking at it retrospectively and considering the new scholarly evidence, I think it would not be too strong a statement to grant Plotinus such a title. One may concede that even St. Augustine himself - to the extent that he held the distinction of double activity in divinity and built further on it - owes a great deal of the development of his ideas to the Plotinian account.

To obtain an accurate grasp of Plotinus' metaphysical account and worldview is not an easy task. For it concerns a view of a large world. ${ }^{8}$ The reader of the Enneads will soon come to understand that Plotinus' metaphysics, as indeed his entire philosophy, is the result of a complicated, often controversial in its parts, yet overall coherent, reconstruction of reality from the first principle to the wholeness of being, which is unprecedented in the history of philosophy. A major difficulty in comprehending this reconstruction lies on the fact that, despite its originality, Plotinus' thought is 'backward-looking,', and therefore a combination of approaches would be necessary for an as complete as possible approach to his world. ${ }^{10}$ One of the great difficulties with Plotinus' texts is that they often contain an enormously condensed amount of information, reflecting the way he wrote his works. As Porphyry testifies, the Enneads were written only after their content was fully conceived in Plotinus' mind. ${ }^{11}$ If that is the case, one could expect the imprints of such condensation not only in the big picture of the Plotinian world but also in its specific parts.

${ }^{5}$ Ibid.

${ }^{6}$ Eyjólfur Kjalar Emilsson, Plotinus, Oxford: Routledge, 2017, 1.

${ }^{7}$ Arthur Hilary Armstrong, "Plotinus", in: A. H. Armstrong (ed.), The Cambridge History of Later Greek and Medieval Philosophy, Cambridge: Cambridge University Press, 1967, 215.

${ }^{8}$ Emilsson, Plotinus, 1.

${ }^{9}$ Ibid.

${ }^{10}$ For the main methodologies, the available paths that Plotinian scholarship has found suitable for entering into Plotinus' world, see, Emilsson, Plotinus, 2.

${ }^{11}$ Porphyry, Vit. Plot. 8, 1-8. I use Armstrong's translation of the Enneads. 
One of the most central parts of the Plotinian metaphysical account consists, without doubt, in the concept of participation. Participation $\left(\mu \frac{1}{\varepsilon} \theta \varepsilon \xi 1 \zeta\right)$ has been a fundamental concept ever since Plato's theory of Forms. In the Platonic system it illustrates the bond connecting the realm of ideas with the world of sensible beings. Certainly, there is much that goes on between Plato's Parmenides and Plotinus. But it is also true that Plotinus takes over the concept of participation and brings it to the front of the Neoplatonic stage, enhanced now with a new capability of serving the increased complexity that the Plotinian metaphysical hierarchy demonstrates. Plotinus' concept of participation would not have developed efficiently without the aid of a concept that should be considered as fundamental to participation. This is the concept of aptitude.

The main aim of the paper is to argue for the value of this concept within the Plotinian worldview. This value may be better appreciated if one gets not only a glimpse of Plotinus' metaphysics but also an awareness of the impact his thought exercised to the Christian metaphysical developments where aptitude plays a central role as well. ${ }^{12}$ Thus, prior to enter to the section on epitédeiotes I address some aspects of the interface between Plotinus and Christian thought. Next follows the main discussion on epitédeiotes, which is enriched by certain insights into the Plotinian reality of participation. My examination of the concept of aptitude develops in connection with a significant property of the Plotinian hierarchy, that of consubstantiality.

\section{Plotinus and Christianity}

Plotinus' thought is worth studying. Not only because it offers invaluable interpretations of Plato's doctrines and new accounts that shape a novel understanding of the cosmos. But also because he has become a constant 'interlocutor' with many Church fathers whose philosophical developments of Christian doctrine were built upon either positive appropriations of Plotinian Neoplatonism or critical transformations of it. Interestingly, as Dermot Moran rightly notes, 'Plotinus was regarded as sympathetic to Christianity and was translated into Latin by the Roman senator and convert to Christianity Marius Victorinus. ${ }^{13}$ To broaden this remark so as to include both Western and Eastern Christianity would not be wrong; Synesius of Cyrene's 'connection between soul's higher generative sources and its

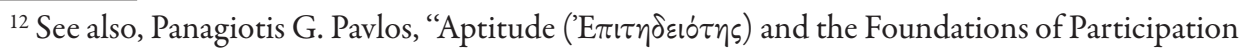
in the Philosophy of Dionysius the Areopagite", Studia Patristica XCVI, Papers Presented at the Seventeenth International Conference on Patristic Studies held in Oxford 2015, M. Vinzent (ed.), Leuven: Peeters, 2017, 377-396.

${ }^{13}$ Dermot Moran, "Neoplatonism and Christianity in the West", in: Pauliina Remes and Svetla Slaveva-Griffin (eds.), The Routledge Handbook of Neoplatonism, London: Routledge, 2014, 512. 
earthly permutations' infused from Plotinus, is just an example. ${ }^{14}$ These claims can be further supported by the fact that not only philosophers but also patristic scholars engage with the thought of Plotinus in fruitfully addressing issues, such as the priority of unity and simplicity to multiplicity and diversity and the endless progress of beings in the stability of divine goodness, ${ }^{15}$ the notion of free will - formulated by

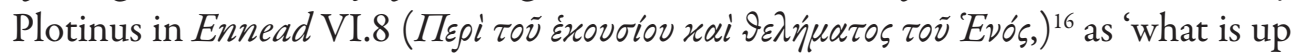

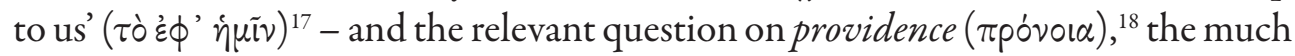
favoured by Plotinus, as well as by many Neoplatonists image of the circle, ${ }^{19}$ the doctrine of the Logos and the logoi, ${ }^{20}$ the doctrine of double activity, ${ }^{21}$ and its relation to

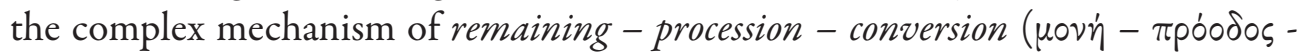
$\dot{\varepsilon} \pi \iota \tau \tau \rho \phi \dot{\eta}),{ }^{22}$ to mention but a few. ${ }^{23}$

Much could be said about the presence of Plotinus in the works of St. Gregory of Nyssa; the latter had thoroughly read the former. ${ }^{24}$ Igor Pochoshajew considers the Plotinian spiritual heritage interwoven with the question of the importance of Platonism as a whole in Gregory's thought. ${ }^{25}$ St. Gregory, however, unlike Euse-

${ }^{14}$ Dimitar Dimitrov, "Neoplatonism and Christianity in the East: philosophical and theological challenges for bishops", in: P. Remes and Sv. Slaveva-Griffin, Handbook of Neoplatonism, 527.

15 Pascal Mueller-Jourdan, "The Foundation of Origenist Metaphysics", in: Pauline Allen and Bronwen Neil (eds.), The Oxford Handbook of Maximus the Confessor, Oxford: Oxford University Press, 2015, 153-155.

${ }^{16}$ Plotinus, Enn. VI.8.1, 17-18; (On Free Will and the Will of the One).

${ }^{17}$ See also, Raymond J. Laird, "Mindset ( $\left.\gamma \nu \omega \dot{\mu} \eta\right)$ in John Chrysostom”, in: P. Allen and Br. Neil, Handbook of Maximus the Confessor, 201.

${ }^{18}$ Bronwen Neil, "Divine Providence and the Gnomic Will before Maximus", in: P. Allen and Br. Neil, Handbook of Maximus the Confessor, 236.

${ }^{19}$ Torstein Theodor Tollefsen, “Christocentric Cosmology", in: P. Allen and Br. Neil, Handbook of Maximus the Confessor, 310-311.

${ }^{20}$ John M. Rist, Plotinus. The Road to Reality, Cambridge: Cambridge University Press, 1967, 84-102, and Tollefsen, Handbook of Maximus the Confessor, 312-314.

${ }^{21}$ Eyjólfur Kjalar Emilsson, "Remarks on the Relation between the One and Intellect in Plotinus", in: J.J. Cleary (ed.), Traditions of Platonism. Essays in Honour of John Dillon, Aldershot: Ashgate, 1999, 271-290, and Torstein Theodor Tollefsen, Activity and Participation in Late Antique and Early Christian Thought, Oxford: Oxford University Press, 2012, 25-27.

22 Tollefsen, Handbook of Maximus the Confessor, 314-315.

${ }^{23}$ There is much left out of here. Indicatively, one may also check, Vladimir Lossky, The Mystical Theology of the Eastern Church, Crestwood: St. Vladimir's Seminary Press, 1957, 46-49, Vladimir Lossky, The Vision of God, Crestwood: St. Vladimir's Seminary Press, 1973, 121-123, Placid Spearritt, A Philosophical Inquiry into Dionysian Mysticism, Fribourg: University of Fribourg, 1968, 53, Anthony Meredith, "Gregory of Nyssa", in: Lloyd P. Gerson (ed.), The Cambridge History of Philosophy in Late Antiquity, vol. 1, Cambridge: Cambridge University Press, 2010 [2010i], 477-480, Tollefsen, Activity and Participation, 64-66 and 107-110, and Emilsson, Plotinus, 37-69.

${ }^{24}$ Pierre Maraval, "Biography of Gregory of Nyssa", in: Lucas Francisco Mateo-Seco and Giulio Maspero (eds.), The Brill Dictionary of Gregory of Nyssa, VCS, 99, Leiden: Brill, 2010, 104.

${ }^{25}$ Igor Pochoshajew, "Plotinus", in: L.Fr. Mateo-Seco and G. Maspero, Gregory of Nyssa, 629. 
bius of Caesarea, neither refers on any occasion to Plotinus by name, nor does he quote him verbatim. ${ }^{26}$ Anthony Meredith shows that, St. Gregory of Nyssa's exegetical method in commenting on the presence of God that Moses had experienced on



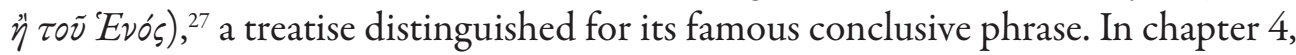
Plotinus confesses that the great many aporiai humans experience in seeking to interpret their experiences of the One derive from the fact that 'our awareness of that One is not by way of reasoned knowledge or of intellectual perception, as it happens with other intelligible beings, but by way of a presence superior to knowledge'



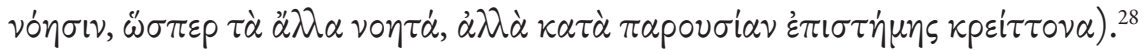

This passage is important. For here Plotinus points to the experience of a presence that transcends knowledge and thinking. As such, one may rightly assume that what is implied here is the reality of Plotinian ekstasis ( $\varepsilon^{\prime} \kappa \sigma \tau \alpha \sigma\llcorner\zeta$, being out of oneself), ${ }^{29}$ which emerges from the absolute transcendence of the One, perfectly illustrated in the passage. ${ }^{30}$ But it remains questionable whether Plotinus' idea of deification illustrated with ekstasis could be accepted by, and considered in accordance with, the notion of deification of Christian thinkers that depends on the under-

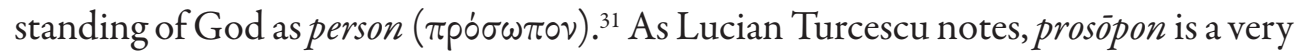
sophisticated concept developed by Gregory of Nyssa in his attempt to clarify the paradox of the Holy Trinity; that is, how a single God, whom presumably Plotinus acknowledges as the One, comprises three distinct Persons. ${ }^{32}$ It is impossible to enter here into such a subject. However, the reader should be aware of the high relevance of the discussion of St. Gregory to the Plotinian vertical hypostatic setting. One may think that had Plotinus not developed his influential account of the three hypostases the way he did it, fourth-century Church fathers would, perhaps, have not need-

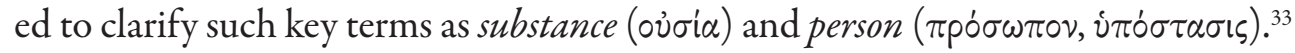

Moreover, Vladimir Lossky tells us how much efforts St. Gregory of Na-

${ }^{26}$ Anthony Meredith “Neoplatonism”, in: L.Fr. Mateo-Seco and G. Maspero, Gregory of Nyssa, 531.

${ }^{27}$ Meredith, Gregory of Nyssa, 477, especially his discussion on Gregory of Nyssa and Plotinus on Evil: 480-41, and Alden A. Mosshammer, "Evil", in: L.Fr. Mateo-Seco and G. Maspero, Gregory of Nyssa, 325-330.

${ }^{28}$ Plotinus, Enn. VI.9.4, 1-4; (On the Good or the One).

${ }^{29}$ Plotinus, Enn. VI.9.11, 22-25.

${ }^{30}$ Jens Halfwassen, "The Metaphysics of the One”, in: P. Remes and Sv. Slaveva-Griffin, Handbook of Neoplatonism, 191.

${ }^{31}$ Norman Russell, The Doctrine of Deification in the Greek Patristic Thought, Oxford: Oxford University Press, 2006, 313 and 318-319.

${ }^{32}$ Lucian Turcescu, "Person", in: L.Fr. Mateo-Seco and G. Maspero, Gregory of Nyssa, 591.

${ }^{33}$ Ibid. 
zianzus made to 'win the philosophers to the contemplation of the Trinity. ${ }^{34}$ The practice St. Gregory of Nazianzus followed, which was only common to all great Christian thinkers, is responsible for the great similarity of conceptual occurrences common in Church fathers and in Plotinus. One example of such an occurrence



There are certain aspects of the Neoplatonist reconstruction of the world that are fundamental and they locate in the forestage of the Neoplatonic metaphysical drama. These are, a) the central notions of the three hypostases systematized

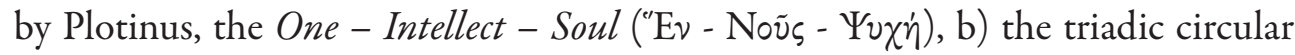

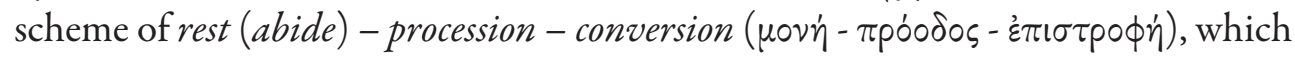
in fact derives from the understanding of the hypostases and fills in, so to say, the

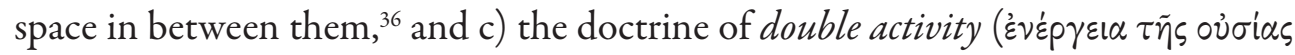

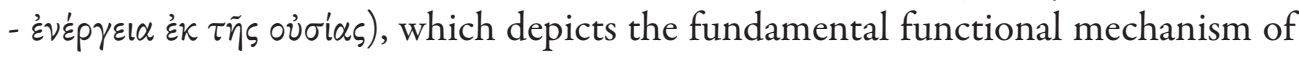
every hypostasis, in other words illustrates the 'mode of being' of a hypostasis. As I have already mentioned, central to this conceptual representation of the cosmos is the concept of participation, already developed by Plato, which is now brought to the fore by Plotinus, enhanced with an increased performance and adapted to serving the complexity that his metaphysical hierarchy demonstrates. Much to this increased performance is due to the Plotinian elaboration of the concept of aptitude.

\section{Aptitude}

In general, the term epitédeiotes designates a capacity or suitability for something. ${ }^{37} \mathrm{It}$ refers to the capacity a being possesses for performing an action, whether this action is innate to that being, and therefore should be understood as change, or it has an external effect or product. By the term 'being' one may understand both living and lifeless entities. To draw two examples from the experience of daily life and from natural reality respectively, a carpenter has a specific capacity that allows for wooden artifacts. Such a person possesses an aptitude for elaborating wooden materials in ways profitable to daily life or for esthetic purposes. At the same time, human beings in

${ }^{34}$ Lossky, Mystical Theology, 46. Lossky draws extensively on Plotinus, in his endeavor of similarities and differencies between Neoplatonism and Christian thought; see also, Lossky, Vision of God, 121-123.

${ }^{35}$ Lossky, Mystical Theology, 49.

${ }^{36}$ Certainly, there are restrictions in applying this triad to the first hypostasis, the One.

${ }^{37}$ The following linguistic remarks on epitédeiotes may be useful to the reader. Chantraine (Pierre Chantraine, Dictionnaire Étymologique de la Langue Grecque. Histoire des Mots, Paris: Éditions

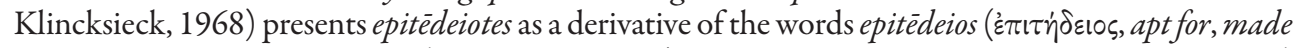
for an end or purpose, convenient), and ta epitédeia ( $\tau \dot{\alpha} \dot{\varepsilon} \pi \imath \dot{\eta} \dot{\delta} \varepsilon 1 \alpha$, requisites, things necessary for living) [for the English renditions of the Greek terms I have consulted the respective lemmas, in: Henry George Liddel and Robert Scott (eds.), A Greek-English Lexicon, New York: Oxford University Press, 
general possess the capacity to become carpenters whether they put it into work or not. In contrast to the aptitude for making wooden artifacts, the actualization of the capacity to become a carpenter amounts to a change without any visible effect, unless a carpenter proves his or her skills in action; otherwise, carpenters look like all other human beings. On the level of natural reality, an inanimate being, a natural element, say fire, has a capacity to perform an activity that extends its effects beyond the agent. Indeed, fire has the capacity to heat and burn any object brought into contact with it; a heated or burning body is an effect of the capacity of fire to heat and burn.

It may be observed that in both the above examples there is another aspect of aptitude that is to be located not in the agent itself but in the objects that are involved in the performed action. That is, the wooden material on the one hand, and the medium that is the recipient of the action of fire on the other - for instance, the air that is heated by the fire, or a piece of wood burning in our fireplace. This illustration shows that aptitude is a concept that ought be examined in a twofold manner. In one of these the focus should be on the agent of a certain activity; in this case aptitude is regarded as a capacity connected with an active potency. But aptitude is also to be located in the matter in which the action is enacted, and in this case it should be considered as a capacity connected with a passive potency. This last case relates to a certain aspect of the context in which the notion of aptitude appears in the thought of Plotinus, who seems to regard epitédeiotes as an alternative word for passive potency ( $\delta \dot{v} v a \mu \varsigma \pi \alpha \theta \eta \tau \leftarrow \kappa \dot{n}$ ) or, one may say, a type of passive potency.

This sketchy description of aptitude may generate a fundamental question to the reader. One may wonder, what is that content of epitédeiotes that comes ad extra to what is signified with the Aristotelian notion of potentiality ( $\delta v v \alpha \mu \varepsilon \varepsilon)$. In other words, what does the concept of aptitude bring about, other than what we get through the Aristotelian distinction between potentiality and actuality? Samuel Sambursky has made some useful relevant remarks. He notes that 'potentiality is

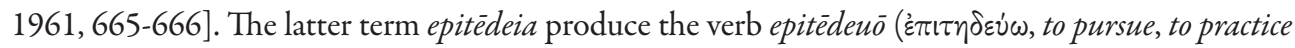

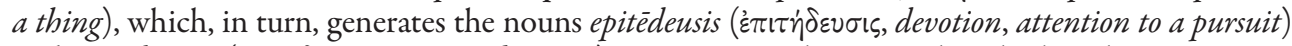

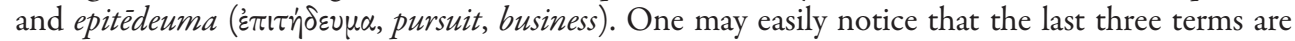
quite often in use both by Plato and Aristotle in political and moral contexts (see, for instance, Plato, Laws 778a7-8; 791d8-9; 968d1-3, Plato, Republic 374e4, and Aristotle, Athenians'Republic 42, 2:6-8;

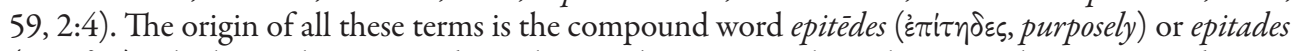
$(\dot{\varepsilon} \pi i \tau \alpha \delta \varepsilon \varsigma)$, which, as Chantraine admits, has an obscure etymological origin. Chantraine renders epi-

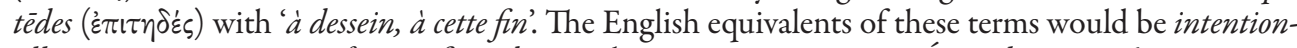
ally, on purpose, or even of a specific end, see, Chantraine, Dictionnaire Étymologique, 361. One may reasonably think that such a terminological frame argues not only for the relational mode, so to speak, of epitédeiotes but also for a strong personal orientation of it and of terms kin to it. With 'personal orientation' I wish to stress that epitédeiotes is primarily qualified, and obtains its completeness, on the grounds of presence of an agent. With 'agent' I denote that genre of beings that are able to act freely from determinism. This should need a detailed justification, but I shall not enter into it here. 
only a necessary condition for actuality but it need not be a sufficient one. ${ }^{38}$ In exemplifying the case he raises the question whether every illiterate is potentially a man who can read and write, and he answers that, 'such a person is so only if he possesses the faculty of learning the art of reading. So for Sambursky epitédeiotes is a technical term that signifies the sufficient condition for the actualization of certain potency. He notes that it came into use as a definite scientific concept in the second century A.D. ${ }^{39}$ When it comes to the Plotinian use of the term, he admits what is said later in this paper in connection with 'differentiated participation', namely that epitédeiotes is introduced by Plotinus in order to illustrate his doctrine of the different degrees of participation in the Intelligible in spite of its presence everywhere as a whole.' ${ }^{40}$

Plotinus' concept of aptitude emerges from and expands on his cosmic visualization. What is the position of epitedeiotes in this vision? What is the intellectual mission of the concept? Does the concept emerge exclusively in a specific aspect of Plotinian metaphysics, or does it pervade the whole of it? Should one consider Plotinus' account of aptitude developing by means of usages of the term epitédeiotes and its derivatives, or is there any wider group of terms and formulations that establish the concept as well? Could the notion of aptitude be associated with the emergence of the Plotinian hierarchy, and, if so, how? Should, for instance, aptitude of beings be considered as a cause for, or an effect of, the hierarchical structure of the universe? Moreover, are there any reasons why Plotinus should be claimed as an innovator who renews the concept in addressing questions that have not been raised before? In what follows I attempt to address these questions. In doing so I discuss parameters central to Plotinus' metaphysics and related to the concept of aptitude that I deem necessary in such an inquiry.

It is true that Plotinus employs the term epitédeiotes within a context similar to what we find it later in the thought of Proclus and Dionysius the Areopagite. But the frequency with which the term occurs in the Enneads is rather low. Epitédeiotes

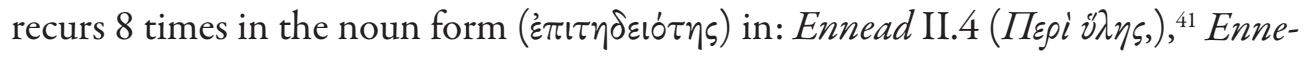

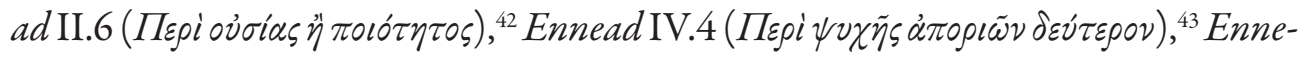

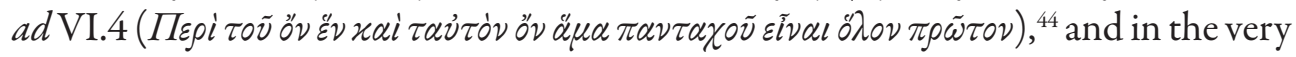

${ }^{38}$ Samuel Sambursky, The Physical World of Late Antiquity, London: Routledge and Kegan Paul, 1962, 106.

${ }^{39}$ Ibid.

${ }^{40}$ Sambursky, Physical World, 107.

${ }^{41}$ Plotinus, Enn. II.4.7, 3; II.4.11, 28: (On matter).

42 Plotinus, Enn. II.6.2, 29: (On Substance, or On Quality).

${ }_{43}$ Plotinus, Enn. IV.4.23, 3: (On Difficulties about the Soul II).

${ }^{44}$ Plotinus, Enn. VI.4.11, 4; VI.4.15, 2; VI.4.15, 13: (On the Presence of Being, One and the Same, everywhere as a Whole I). 


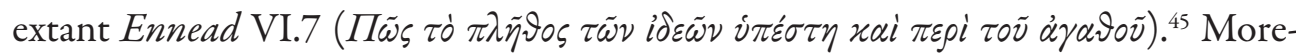

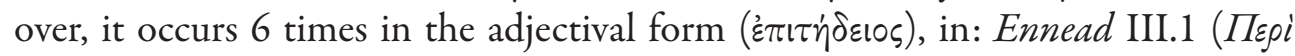

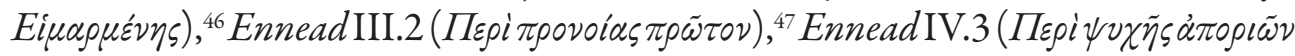
$\pi \rho \tilde{\omega} \tau o \nu),{ }^{48}$ Ennead IV.4 ${ }^{49}$ Ennead VI. $4,{ }^{50}$ and twice in the adverbial form (ह่ $\left.\pi ı \tau \eta \delta \varepsilon i \omega \varsigma\right)$,

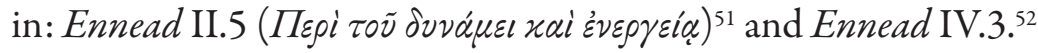

Such a rare use may indeed prevent one from acknowledging the significance which the concept has in Plotinus' participatory metaphysical account. Indeed, if one is to comprehend aptitude's role and function in Plotinian thought, one might take into consideration a wider conceptual frame within which the term is recruited. For it is true that a thinker may often develop his accounts in ways that go far beyond the frames that are marked by specific terminological illustrations. In other words, it is likely that a whole account is present in a philosophical text or context without a single instance of the relevant terms that serve as key elements of the corresponding conceptual construction..$^{53}$ To put it simply, the concept of aptitude may well be present implicitly in texts and contexts, even if the term epitédeiotes is not in use. Plotinus employs a wide range of notions that point a) to the notion of epitédeiotes, and b) to the reality of participation. Equivalent to epitédeiotes are the terms a) ability to receive, generally denoted by dechesthai duna-

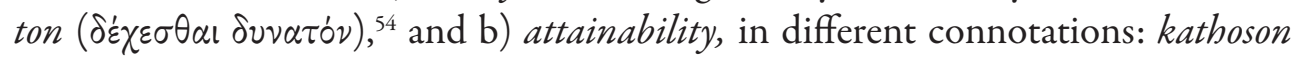

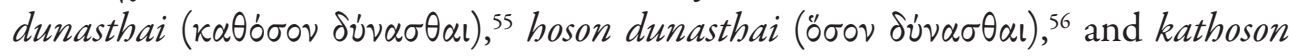

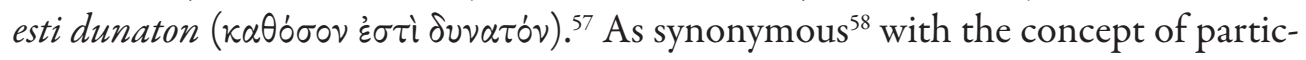
ipation the following concepts should be considered: a) approach ( $\pi p \circ \sigma \varepsilon p \chi \varepsilon \sigma \theta \alpha \mathrm{l})$

${ }^{45}$ Plotinus, Enn. VI.7.7, 8: (How the Multitude of the Forms came into being, and on the Good).

${ }^{46}$ Plotinus, Enn. III.1.1, 35: (On Destiny).

${ }^{47}$ Plotinus, Enn. III.2.13, 10: (On Providence I).

${ }^{48}$ Plotinus, Enn. IV.3.17, 5: (On Difficulties about the Soul I).

${ }^{49}$ Plotinus, Enn. IV.4.23, 29 and 31.

${ }^{50}$ Plotinus, Enn. VI.4.15, 2.

${ }^{51}$ Plotinus, Enn. II.5.2, 22: (On What exists potentially and what actually).

52 Plotinus, Enn. IV.3.8, 51.

53 Torstein Theodor Tollefsen, "Did St. Maximus the Confessor Have a Concept of Participation?", Studia Patristica XXXVII, Papers Presented at the Thirteenth International Conference on Patristic Studies held in Oxford 1999, Cappadocian Writers, Other Greek Writers, M.F. Wiles and E.J. Yarnold (eds.), Leuven: Peeters, 2001, 625.

${ }^{54}$ Plotinus, Enn. VI.4.2, 49.

${ }^{55}$ Plotinus, Enn. VI.4.8, 40.

${ }^{56}$ Plotinus, Enn. VI.4.15, 6.

57 Plotinus, Enn. VI.5.3, 15-16.

58 The term synonymous ( $\sigma \nu \nu \dot{\omega} v v \mu \alpha$ ) should not be taken here in the strict Aristotelian sense in which it appears in the Categories. Rather, I use it only in concordance with the second part of Aris-

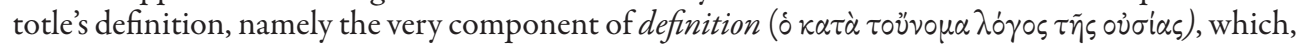
in our case, is the concept of participation. See also, Aristotle, Cat. 1a6-8. 


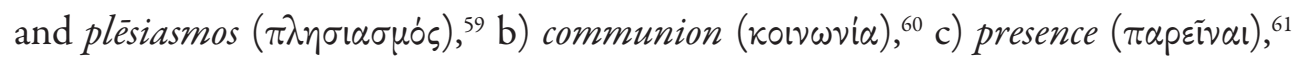
in the specific instantiation of omnipresence ( $\pi \alpha \nu \tau \alpha \chi \circ \tilde{v}$ Eival), ${ }^{62}$ and d) metalēpsis $(\mu \varepsilon \tau \alpha \lambda \alpha \mu \beta \dot{\alpha} \nu \varepsilon เ \nu) .{ }^{63}$

Plotinus' thought constitutes a transition-point in the use of epitédeiotes. He is the first who elaborates the concept in a way that advances its use further, compared to its initial role of designating the transition from potency to actuality and the capacity of matter for receiving the form, as initially conceived by Aristotle and analyzed further by Alexander of Aphrodisias. ${ }^{64}$ Plotinus is the one who, thanks to his detailed insights into the problem of participation, offers a significant contribution to the historical development of aptitude, so that he should be proclaimed an innovator in this respect. In fact, I do believe that Plotinus opens up a new horizon to aptitude, leading it beyond its natural context. In speaking of natural context I simply refer to the usage of the term by the Commentators of Aristotle, and especially Alexander, in an attempt to designate the inherent capacity, as Dodds asserts,

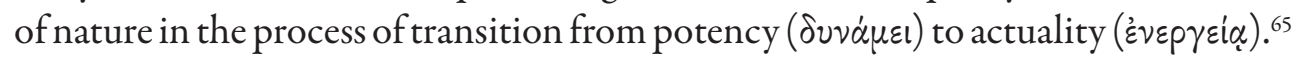
But why should one assert that with Plotinus aptitude is upgraded and designates a component, and a particular expression, of the central doctrine of receptivity according to the capacity of the recipient? What is this about?

Plotinus' thought on the concept and the respective doctrine of receptivity proportional to the capacity of the recipient initially marked by Armstrong, evolves -as a large amount of secondary literature shows- in the central treatise on the omnipresence of being, Ennead VI.4-5. ${ }^{66}$ The classification of Plotinus' works by his disciple Porphyry provided Ennead VI.4-5 with a title that denotes the complexity of the question at issue: 'On the Presence of Being, One and the Same, Everywhere as a Whole. The treatise is of particular interest. It deals with issues that shape the backbone of Plotinus' metaphysical account, such as the nature of the Soul, the relationship of partial soul to the body, and the nature of participation. Here the

\footnotetext{
${ }^{59}$ Plotinus, Enn. VI.5.8, 20.

${ }^{60}$ Plotinus, Enn. VI.4.16, 14.

${ }^{61}$ Plotinus, Enn. VI.4.2, 39.

62 Plotinus, Enn. VI.4.1, 13.

${ }^{63}$ Plotinus, Enn. VI.4.8, 11.

${ }^{64}$ Apart from Porphyry's evidence in his Life of Plotinus about the circulation of the works of Alexander of Aphrodisias in Plotinus' circle in Rome, there are additional reasons that prompt me to hold that Alexander was an inspiring thinker for Plotinus on the matter. I shall discuss them elsewhere.

${ }^{65}$ Eric R. Dodds (ed.), Proclus. The Elements of Theology, Oxford: Clarendon Press, 1963, 344.

66 The most recent study shedding light on this Ennead and, consequently, on aptitude is Eyjólfur Kjalar Emilsson and Steven Keith Strange (eds.), Plotinus. Ennead VI.4-5, On the Presence of Being, One and the Same, Everywhere as a Whole, Las Vegas: Parmenides Publishing, 2015. For detailed bibliography on the topic and additional remarks, see Pavlos, Aptitude in the Areopagite.
} 
concept emerges as a corollary from the treatise's main issue, that is, the problem of the omnipresence of being everywhere, one and the same, as a whole. ${ }^{67}$ Plotinus uses epitédeiotes to account for diversity in the bodily world, differentiation in the degrees of participation, and the 'irresponsibility' of the World Soul for the imperfections of bodily souls. The ideas discussed in Ennead VI.4-5 exercised a tremendous influence on the development both of the reality of participation and the appropriation of the concept of aptitude in Late Antiquity and later. ${ }^{68}$ It is most likely that it was the ideas of this treatise that Thomas Aquinas had in mind in reforming the Neoplatonist view on matter's non-existence and its identification with evil; namely that primary matter, although it may be called non-being on account of its privation, does share to certain extent in goodness by means of its aptitude for goodness ${ }^{69}$ So this treatise is, indeed, a significant source in understanding the perplexities Plotinus faces in dealing with the problem of omnipresence. ${ }^{70}$

The question he is concerned with relates to an old and fascinating metaphysical problem. In fact, it is about one of the fundamental issues deriving from Plato's theory of Forms. Plotinus' agenda comprises the problem of the relation between the sensible and the intelligible, and the omnipresence of being, which, as I have said, Plato first discusses in the Parmenides. ${ }^{71}$ Nowadays it is called the 'sailcloth enigma. ${ }^{72}$ In its Platonic version the problem referred to as the 'sailcloth' enigma is the following. How particular beings, which - according to the basic idea of Plato's theory of Forms - gain their being from the being, the universal and eternal idea of being, have a share of being? Do they partake of being as a whole? Or do they participate in a part of it?

Plotinus develops a certain strategy to solve the problem. He proceeds to elucidate how the reality of participation should be conceived of. Participation emerges within a certain metaphysical conception of the cosmos. As for any genuine Pla-

${ }^{67}$ See, Jonathan Scott Lee, "The Doctrine of Reception according to the Capacity of the Recipient in Ennead VI.4-5”, Dionysius 3, 1979, 79-97, Dominique O’Meara, "The Problem of Omnipresence in Plotinus Ennead VI.4-5: A Reply”, Dionysius 4, 1980, 61-73, and Emilsson and Strange, Plotinus. Ennead VI.4-5.

${ }^{68}$ Stephen Gersh, From Iamblichus to Eriugena, An Investigation of the Prehistory and Evolution of the Pseudo-Dionysian Tradition, Leiden: Brill, 1978, 38 and 53.

${ }^{69}$ Thomas Aquinas, Summa Theologiae, pt. I, qu. 5, art. 3: 'Although, according to the Platonists, primary matter may be said to be a non-being on account of the privation attaching to it, nevertheless, it does participate to a certain extent in goodness, viz., by its relation to, or aptitude for, goodness'. The translation is from the edition of Summa Theologica made by the Fathers of the English Dominican Province. For reading suggestions on the influence of the Plotinian doctrine in the Medieval philosophy and up to Thomas Aquinas' times, see Emilsson and Strange, Plotinus. Ennead VI.4-5, 28-29.

${ }^{70}$ See also, O’ Meara, Problem of Omnipresence.

${ }^{71}$ Plato, Parm. 130a-135c.

${ }^{72}$ Plato, Parm. 131a4-6. See also, Steven Keith Strange, "Plotinus' Account of Participation in Ennead VI.4-5”, Journal of the History of Philosophy, 30:4, 1992, 479. 
tonist faithful to his master, the divine Plato, ${ }^{73}$ for Plotinus too, the starting point is the One, the Good. Plotinus anticipates a first principle of the cosmos. In Ennead V.3 he develops an argument that reflects his hierarchical view of the world. His axiomatic start is that each multiplicity should be deriving from simplicity. As the world of sense is distinguished by multiplicity, the sensible cannot be made by an equally sensible principle but, rather, by something simpler. Anything simpler to sensible multiplicity pertains to the level of the intellect. But the intelligible is distinguished by multiplicity too. Therefore, the intelligible ought to be made by something even simpler to it. The intelligible multiplicity should be deriving by something that is not multiple whatsoever. The need for an ultimate principle leads to that which is ultimately unique, beyond any multiplicity and that is the One. ${ }^{74}$

This argument is the foundation of the methodology of inquiring into the

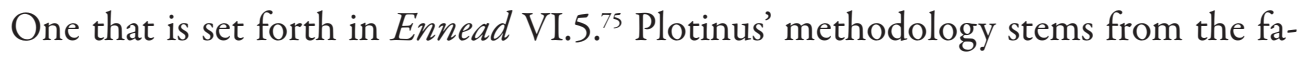
mous juxtaposition between being and becoming, at the opening of Timaeus' narrative. ${ }^{76}$ In order for the inquiry to be fulfilled, Plotinus suggests that one should take principles proper to the intelligible and real substance. Admittedly, the distinction between what is in perpetual motion and what is always in the same condition and remains within itself prompts one to search for respective principles that may be established by means of probable syllogisms.

Thus epitédeiotes should be thought not in the realm of that being which remains in itself, but rather in the world of movement and becoming. I am not rejecting yet, however, the possibility of identifying the presence of a certain aptitude connected with the One's procession, on the condition that Its procession should be conceived of as belonging to a class equal to Its remaining; besides, for Plotinus both states are activities. I can understand that there may be objections to a proposal for locating any kind of aptitude in the One, but let us leave the question open for a while, and focus on the three-hypostatic structure of the all and the concept of double activity. For the Plotinian concept of aptitude develops on the basis of both these conceptions.

The theory of emanation, the cornerstone of Plotinian cosmology, presumes the overflow of the divine good substance - in other words, the internal activity of the One - as the external activity of the first hypostasis. This activity causes the constitution of the other hypostases, namely Intellect and Soul. The relation between

${ }^{73}$ Plotinus, Enn. IV.8.1, 23-24: $\Lambda \varepsilon i \pi \varepsilon \tau \alpha \iota ~ \delta \dot{\varepsilon} \dot{\eta} \mu \tilde{\imath} \nu \dot{\delta} \theta \varepsilon \tilde{\imath}{ } \zeta \Pi \lambda \dot{\alpha} \tau \omega \nu$ (We are left with the godlike Plato). See also, Plotinus, Enn. III.5.1, 6.

${ }^{74}$ Plotinus, Enn. V.3.16, 8-16.

${ }^{75}$ Plotinus, Enn. VI.5.2, 7-18.

${ }^{76}$ Plato, Tim. 28d-29a. 
the degrees of being, the ontological grades, has been an intriguing, and at the same time a substantial issue, because it addresses the inquiry into the ratio of affinity among the primary hypostases, namely the One, the Intellect and the Soul, as Plotinus discusses it in Ennead V.1. What emanates from the One is nothing other than the very substance of It, the only difference being that the emanated is inferior to the One in terms of multiplicity and, therefore, otherness. So the Intellect, being something other than the One, is automatically a hypostasis inferior to It.

Plotinus distinguishes between two states of a hypostasis, starting from the

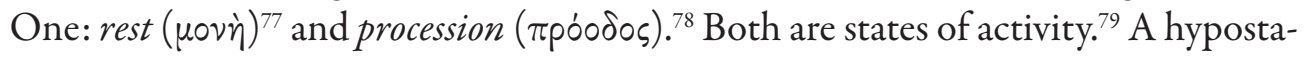
sis is introduced on the basis of an activity constitutive of the same and an activity constitutive of the other. That activity which is constitutive of the same constitutes the substance of the One. Hence, for Plotinus the substance and the activity of the One are identical. One may note, however, that this statement should be accompanied by a clarification. When it comes to the first hypostasis, the One, which is constitutive of the same activity, namely the internal activity of the One, is not identical with its substance in the same way in which this would be applicable to the other hypostases. For the One is beyond substance and, therefore, one should regard Its internal activity as an ambiguous issue, always subject to the qualification of the One as beyond being. Now the fact that the hypostases secondary to the One partake of It is because, being emanated from It, they are not self-sufficient. Their being cannot be taken for granted. They depend on the One and their dependence is precisely expressed in the concept of participation.

\section{Participation}

Participation involves two distinct parts; that which is participated and its participant. The participated is in principle sufficient to itself, so that it does not participate in anything that participates in it. The primary participated is the One, which in the fullness of itself as It is, overflows, as Plotinus argues in Ennead V.2. ${ }^{80}$ This ef-

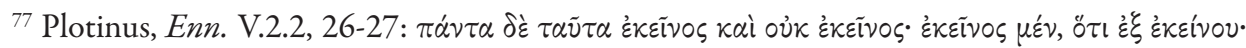

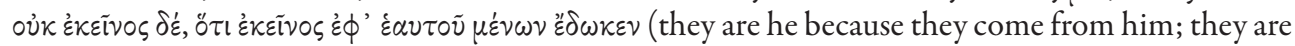
not he, because it is in abiding by himself that he gives them).

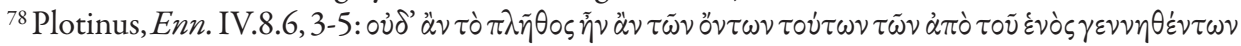

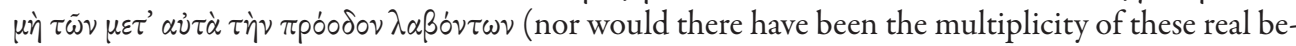
ings which are generated from the One, if the things after them had not taken their way out).

${ }^{79}$ Interestingly, the Plotinian distinction between internal and external activity of the One is assumed by the Areopagite, who rendered it in terms of the fundamental distinction between divine substance, which is imparticipable ( $\left.\dot{\alpha} \mu \varepsilon \theta_{\varepsilon} \xi i \alpha\right)$, and divine activity, which is participable ( $\left.\mu \varepsilon \theta \varepsilon \tau \tau^{\circ} v\right)$. See, Beate Regina Suchla (ed.), CD I, Pseudo-Dionysius Areopagita, De Divinis Nominibus, PTS 33, Berlin: Walter De Gruyter, 1990, XI.6: 222.16, and J.P. Migne, Patrologia Graeca, vol. 3, Paris, 1957, 956a.

${ }^{80}$ Plotinus, Enn. V.2.1, 5-10. 
flux is considered as a transmission of an activity different from the activity that constitutes the entity whence the activity proceeds. While the entity, the hypostasis, remains in itself as internal activity, what overflows from it results in a certain otherness without diminishing the substance - which, in the case of the One is, in

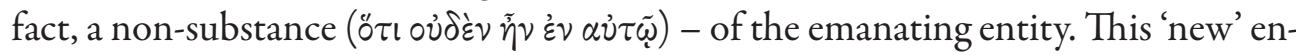
tity, which is inferior to the prior hypostasis, owes its being to the fact that it participates in the prior. That is, it is a participant in the superior entity. Hence, what the participant substantially is, is a participation in what is overflowed, transmitted, as it were, by the participated. The status of being of such a participant should be regarded as a gift, in the sense that it has been granted by the initial source whence the activity proceeded. That means that the participant is only to the extent that it has a share in contemplation of the participated. To be precise, that which is about to become a participant becomes a substance upon halting and gazing towards the source from which it emanated:

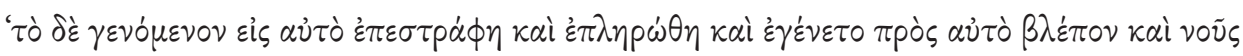

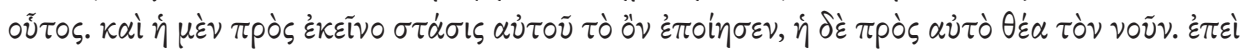

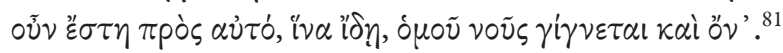

I will not enter into examining the apparent difficulty the above scheme presents. That is, how exactly the external activity produces a hypostasis, and at which stage of the process the hypostasis inferior to its prior emerges. However, the case may be, what is rather clear is that this attitude, the halt and turning of the overflowed towards the One, is that which produces being. Consequently, the vision of the One by this being gives rise to a new hypostasis, in this case Intellect. I hope that this sketchy outline of how a hypostasis is produced may be helpful in understanding what I said above, namely, that a participant is only to the extent it has a share of the participated on the grounds discussed earlier.

Having established that the participated is transmitted in terms of its external activity and constitutes the participant, the latter being a distinct entity only upon casting its gaze towards its source, one is prompted to think of reception by the participant as being equal to such transmittance. But is it truly so? Plotinus sees that what the participated does is to transfer theoria, which is to be received by the participant; the first procession, that of the Intellect from the One, involves a certain vi-

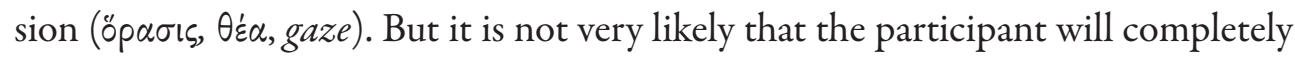
partake of what is transferred. For there are restrictions extending their effect to the

${ }^{81}$ Plotinus, Enn. V.2.1, 10-13: 'This, when it has come into being, turns back upon the One and is filled, and becomes Intellect by looking towards it. Its halt and turning towards the One constitutes being, its gaze upon the One, Intellect. Since it halts and turns towards the One, that it may see, it becomes at once Intellect and being. 
reception of what is transmitted. What do these restrictions amount to? Plotinus' conviction is that they do not bind the participated at all. There are restrictions that occur exclusively in the participant. One way to conceive of these restrictions is in terms of difference. I would codify this idea with the term 'differentiated participation'. Perhaps the best illustration of differentiated participation is to be found at the beginning of chapter 3 in Ennead IV.3, the first of two treatises $\Pi_{\varepsilon \rho i} \psi v \chi \tilde{\eta} s \dot{\alpha} \pi \circ \rho i \tilde{\omega} v$ :

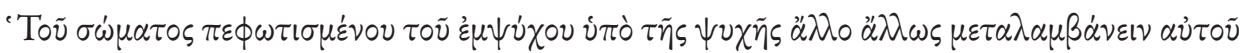

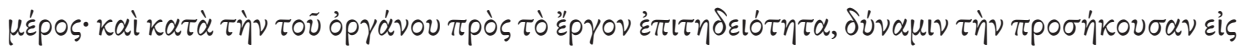
$\tau$ ¿̀ है



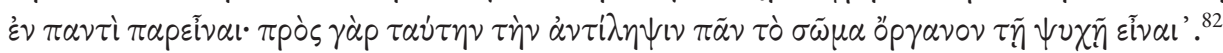

Plotinus locates in the human being a multitude of faculties. These faculties are active in accordance with the aptitude demonstrated in their respective instruments. At the same time, bodily being as a whole demonstrates an aptitude in instrumentally serving the (bodily) soul. What does the holistic service of the body to the soul account for? One may assume that, for Plotinus, bodily functions ought as a whole to support the soul in maintaining her status of affinity with the divine in an unaffected state. At least this seems to be the idea behind the non-communion of the soul with the body. In Ennead IV.7, we see Plotinus' principal concern regarding the affinity of the soul that is present in the human being with divinity. His concern is to manifest the condition on which the human partial soul has an aptitude for participating in the unitary world Soul and through it in the One. The restrictions I mentioned above define the degree of reception of what is transmitted from the participated according to what is called the receptive capacity of the participant, or aptitude. ${ }^{83}$

Why does Plotinus proclaim the integrity, so to speak, of the participated? My suggestion is that in developing such a doctrine Plotinus wants to prohibit one from charging the participated with any imperfect participation. In other words, what Plotinus is convinced about is that any deficiency or lack of perfection, or incapacity for participation charges the participant, namely the receiver. Evidently, aptitude emerges in this context in connection to the two components of participation. Participation consists both in a transferring ( $\mu \varepsilon \tau \dot{\alpha} \delta \circ \sigma / \zeta)$ of the participated and

${ }^{82}$ Plotinus, Enn. IV.3.23, 1-9; (On Difficulties about the soul I): 'When the ensouled body is illuminated by soul, one part of it participates in one way and one in another; and according to the adaptation [aptitude] of (each) sense-organ to its task, as soul gives (each) the appropriate power for its task, so the power in the eyes is called that of sight, the power in the ears that of hearing, and the power of taste is said to be present in the tongue, that of smell in the nostrils, and that of touch in the whole body: for the whole body is sense-organ to the soul for this perception'.

${ }^{83}$ See also, Arthur Hilary Armstrong, The Architecture of the Intelligible Universe in the Philosophy of Plotinus, An Analytical and Historical Study, Cambridge: Cambridge University Press, 1940, 60. 
in reception ( $\mu \varepsilon \tau \dot{\alpha} \lambda \eta \psi \mid \varsigma)$ of it from the participant. This transferring is unbounded, perfect, unlimited and super-abundant, precisely as its source is; whereas reception may be limited, since it is dependent on the receptive ability of the participant.

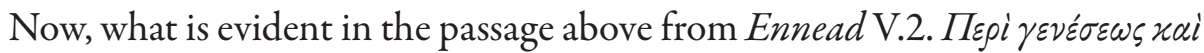
$\tau \dot{\alpha} \xi \varepsilon \omega \varsigma \tau \tilde{\omega} \nu \mu \varepsilon \tau \dot{\alpha} \tau \tilde{\omega} \nu \pi \rho \dot{\omega} \tau \omega \nu$ (On the Origin and Order of Beings which come after the First) is that the overflow itself should not be identified with a hypostasis. There seems clearly to exist a pre-hypostatic state, so to speak, which, although it may be acknowledged as otherness, yet it should not be identified with a distinct hypostasis. For as Plotinus explains, the hypostasis is formed when this otherness, the product of the overflow, ceases to proceed and for some reason feels the urge to turn back to its source. Here one encounters a tough question that Plotinus does not seem to answer in manner that is other than psychological. The question is, how and why the emanation generates entities inferior to the One and imperfect compared to It, which - at the same time - desire to return to the One and seek perfection? I shall return to this point later on.

\section{Consubstantiality}

Plotinus admits that the account of the three primary hypostases is not his own invention but merely an explication of what Plato already knew:

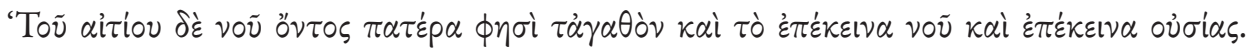

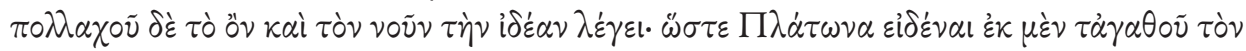

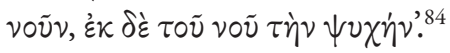

In interpreting Plato, Plotinus establishes a hierarchy that consists of the Good ( $\alpha \gamma \alpha \theta \dot{0} v)$, the Intellect (voṽ $\varsigma)$ and the Soul ( $\psi v \chi \dot{\eta})$. In this hierarchy, nature, the sensible realm, is located within the third hypostasis, the World Soul, and more specifically, its gradations, the individual souls. One may note that the Soul - and, consequently, according to Plotinus' argument in chapter 6 of Ennead VI.4, individual souls too - is consubstantial (óoov́rios) with the primary hypostasis, the One, the Good, God. Surprisingly, and in spite of what one would expect, Plotinus does not frequently use the term homoousion. I say surprisingly, because, if one wishes to be consistent with the Plotinian conception of metaphysical hierarchy, one should take consubstantiality to be a necessary predicate for all beings deriving

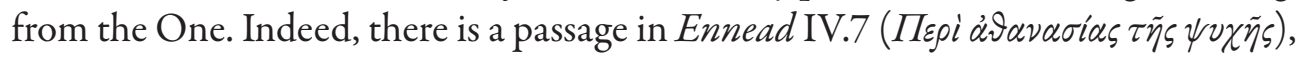
which, in my opinion, clearly supports my claim. Here Plotinus supplies us with the dual status of the soul:

${ }^{84}$ Plotinus, Enn. V.1.8, 8-10; 'And the father of Intellect which is the cause he calls the Good and that which is beyond Intellect and 'beyond being'. And he also often calls Being and Intellect Idea: so Plato knew that Intellect comes from the Good and Soul from Intellect'. 


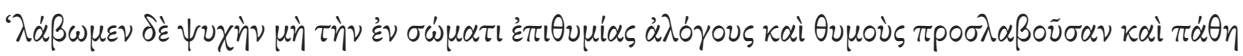

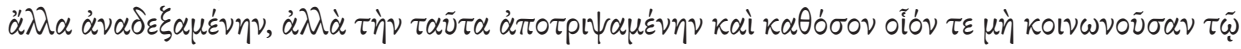

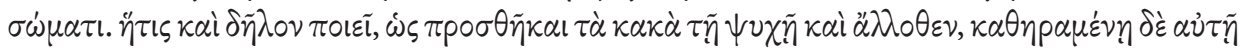

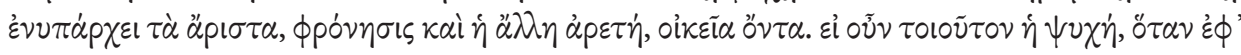

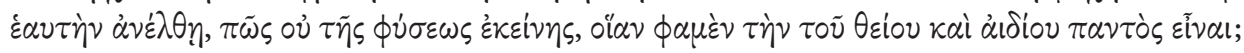

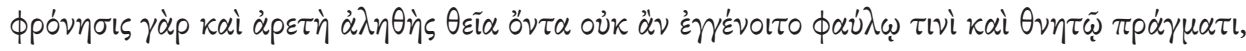

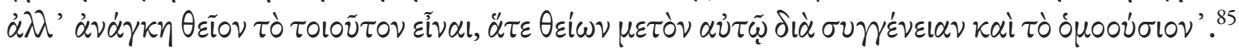

There are two states of the soul. The first is that of the soul which 'has acquired irrational desires and passions and admitted other affections.' The second is that of the soul 'which has wiped these away and which, as far as possible, has no communion with the body'. That the above bring about alternative states of one and the same soul becomes evident if one pays attention to the referential 'as far as possible'. This expression presumes an embodied soul, in which the alternatives occur as dependent on the degree of the soul's virtuous life. Virtuous life consists precisely in the ascending reversion of the soul towards herself ( $\left.\dot{\varepsilon}^{\prime}{ }^{\prime} \dot{\varepsilon} \alpha \nu \tau \dot{\eta} \nu \alpha^{\alpha} \nu \circ \delta \circ \varsigma\right)$. The reversive ascension of the soul is possible because of her affinity with the divine. The divine origin of the soul is clearly stated as necessity and is posited by Plotinus along

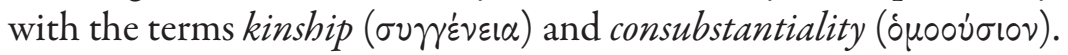

A kinship of the soul with the most divine and eternal nature is acknowledged. Divine reality has a genuinely good and prudent life. Similarly, given that the soul demonstrates an affinity with divine nature, it must itself have the same characteristics. Moreover, this kinship should be regarded as a qualification of the soul, such that prohibits us from identifying a particular soul as body. For divinity pertains to the intelligible, which, in turn, is distinguished by no spatial or temporal divisibility. Divisibility, both in terms of space and time, is a property that occurs in the sensible. Besides, as Plotinus explains, prudence and virtue, being divine, could not abide in some trivial mortal being; rather such a being, viz. the soul, should be divine as well, since it partakes of divine things precisely on the grounds of its kinship and consubstantiality. This very passage, though unique in the entire body of the Enneads, suffices to offer evidence for a fundamental qualification of beings within the Plotinian ontological hierarchy: since beings derive from the One as effects of the chain of consecutive external activities of the hypostases, they have to be consub-

${ }^{85}$ Plotinus, Enn. IV.7.10, 1-20; (On the immortality of the soul): 'Let us take soul, not the soul in body which has acquired irrational desires and passions and admitted other affection, but the soul which has wiped these away and which, as far as possible, has no communion with the body. This soul does make it clear that its evils are external accretions to the soul and come from elsewhere, but that when it is purified the best things are present in it, wisdom and all the rest of virtue, and are its own. If, then, the soul is something of this kind when it goes up again to itself, it must surely belong to that nature which we assert is that of all the divine and eternal. For wisdom and true virtue are divine things, and could not occur in some trivial mortal being, but something of such a kind [as to possess them] must be divine, since it has a share in divine things through its kinship and consubstantiality'. 
stantial with It. The alternative option that beings are not consubstantial with the One would be possible only within a non-emanationist account. Such an account, however, does not exist within Neoplatonism; it is only developed by the Christians on the basis of their distinction between created-uncreated (creationism).

Nevertheless, one should not neglect the value the term homoousion holds with respect to aptitude, that Plotinus employs herein. The soul herself has an affinity with divinity. Her affinity stems from the fact that she has her substance in common with the divine substance. If this is so, then one would be correct in remarking that the entire Plotinian ontological hierarchy presupposes the principle of consubstantiality. In this view, the aptitude the soul demonstrates for return to herself is at the same time an aptitude for ascent towards the One. Hence consubstantiality should be acknowledged as a fundamental reality and condition in the Plotinian metaphysics. It enables Plotinus to speak of assimilation to God by means of what

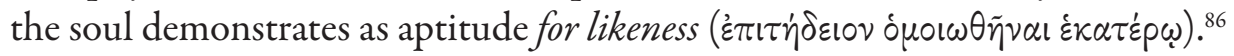

Consubstantiality is that fundamental assumption upon which Plotinus' second and third hypostases emerge as consubstantial otherness to the One. This idea is profound in all successive Neoplatonist metaphysical accounts. Plotinian otherness is established in terms of hypostases demonstrating a partial otherness, or more precisely, an incomplete identity of substance. I am using the expression 'incomplete identity of substance' in order to stress that for Plotinus the degree of identity of substance is dependent on the grade of participation. This, in turn, is regulated by the receptive capacity, the aptitude for participation, of the recipient. It is in this respect that there seems to be a difference between the Plotinian suggestion of consubstantiality and the corresponding Christian account of Dionysius the Areopagite. For Plotinus, assimilation to God is the starting-point and end of metaphysics. The whole setting of reality is primarily based upon the natural affinity the soul has with the divine. That such an affinity is natural entails that it is also necessary. So for Plotinus, assimilation to God is a doctrine grounded on something that should be taken for granted: the divine origin of the soul and its consequent ontological affinity with the divine. Dionysius, however, does not claim any consubstantiality of the soul with divinity. The Christian equivalent to the Neoplatonic likeness to God is not ascertained in terms of an initial, essential affinity between the human being, precisely the soul, and God. For Plotinus the soul has an essential aptitude for assimilation to God. But this does not seem to be the case for the Areopagite. For he would reject Plotinian consubstantiality and he would project a process of deification, which mysteriously develops on the basis of an encounter among ontologically radically different personal hypostases.

${ }^{86}$ Plotinus, Enn. IV.4.23, 29. 
There is, however, a problem here. For if Plotinus is correct in stating that the soul is consubstantial with divinity, then one must expect that all her aptitudes are present to her in imitation of the divine aptitude. But claiming aptitude for divinity would circumvent the very essence of the Plotinian ontology of the One. For Plotinus the One is far from being in any state that involves potency, the latter being considered the ontological state within which aptitude evolves. I cannot provide an adequate solution to this problem herein. As far as I know, Plotinus does not offer an explicitly direct solution either. What I suspect is that he would probably agree with St. Maximus the Confessor in that it would not be proper to seek for aptitudes in divinity. ${ }^{87}$ Maximus' position would probably be partly accepted by Plotinus, to the extent that both would deny complexity in divinity. I say partly, because for Maximus the denial to attribute complexity to divinity, by means of positing aptitude in her, is motivated by the contrast between the uncreated Trinitarian God and the creature within a genuinely creationist viewpoint. ${ }^{88}$ The distinction between created - uncreated, which Maximus acknowledges, is utterly incompatible with the Plotinian emanative account of consubstantiality.

If that is the case, what then, is the source of epitedeiotes in the Plotinian soul? Should it be inquired in its kinship and consubstantiality with the divine? If so, then one should look for aptitude as a divine property. Yet, again, such a viewpoint would be highly problematic. For the divine, insofar as regarded in the One, is simple activity. From this point of view, to seek for aptitude in a state of mere, pure activity would make no sense. Ascribing a notion of aptitude to the One would presuppose that there is something to be achieved; something towards which the One has to move, the notion of movement taken in a broad metaphorical sense here. But there is nothing standing out from the One, nor is there anything that needs to be accomplished by It. The fact that the One is perfect activity and perfectly self-sufficient is by definition against any notion of aptitude present in It. If aptitude designates a capacity of a being for the reception or the accomplishment of something extraneous to It, then this cannot be the case with the One. Its uniqueness and perfection allows no room for us to imagine how there can be anything extraneous to it, at all. Now, if all that is divine is identical with the One in terms of self-sufficiency, then, everything that is divine should not demonstrate any aptitude for anything.

So far we got, so good. But, indeed, is it truly so? This analysis seems to have made clear that it would be rather against the 'nature' of the One to claim for any kind of aptitude in It. Let us have another round of approaching the issue. In Ennead V.1, Plotinus wonders about the Intellect:

${ }^{87}$ Maximus the Confessor, De Charitate IV.8; PG 90, Athens, 2009, 1049b, and George C. Berthold (transl.), Maximus Confessor, Selected Writings, New York: Paulist Press, 1985, 76.

${ }^{88}$ Ibid. 


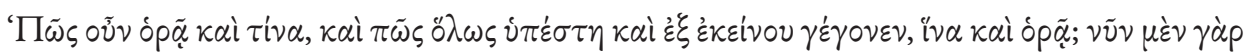

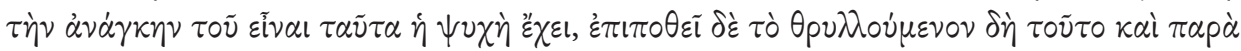

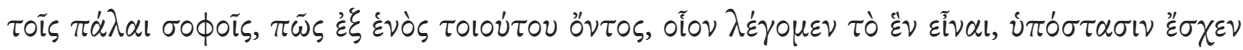

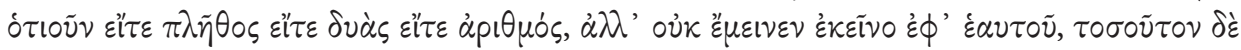

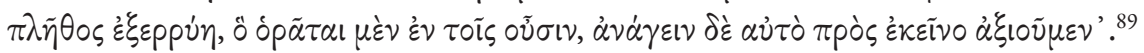

In asking this question, Plotinus does not leave any curious follower unsatisfied. For what he addresses here is the most burning issue that even a young scholar, immediately after a first glimpse of Plotinus' metaphysical hypostatic hierarchy, would wonder about. Why the One, being supreme in the greatest possible degree, blessed in Its self-sufficiency and perfection, without need, complete, beyond any ontological quest, generates multiplicity and does not remain in Itself? Furthermore, how can the One do so and, yet, maintain all the aforementioned characteristics? What is illustrated here is the evident problem that any productive activity of the One would automatically force It to exit from Its immutable eternity. But there is no reason for the One to move out of Itself. Hence, one should exclude any conscious activity of emanation, and consequently, any kind of epitédeiotes related to One's will. Rist confirms my claim concerning non-consciousness in the activity of the One, in asserting that 'there is no conscious turning of the One to the Soul'. ${ }^{9}$ In other words, the self-sufficiency of the One would prohibit any aptitude for generating beings other than Itself - whether should we take the One as being or not.

Yet, the metaphor of overflow (iveppon') still calls us to ponder on the aptitude of what is generated for becoming Intellect, upon seeing the One. To my knowledge, I do not think that Plotinus proceeds to solve this problem directly and in detail. But what I suspect, drawing upon his overall account of the generation of the primary hypostases, the One excluded, is that we may locate the emergence of certain aptitude at the 'moment' when the generated halts and gazes back towards the One, and the Intellect, respectively. That would be, I believe,

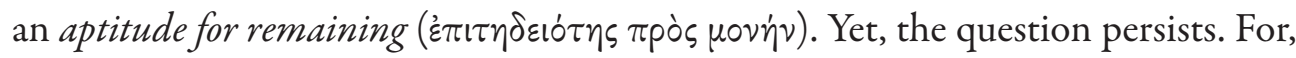
even if we assume that it is fine to acknowledge the One as accountable for the benefaction of this aptitude, how should such an aptitude be qualified? For, pri-

${ }^{89}$ Plotinus, Enn. V.1.6, 1-8: 'How then does it [intellection], and whom does it see? And how did it come into existence at all and arise from the One so as to be able to see? For the soul now knows that these things must be, but longs to answer the question repeatedly discussed also by the ancient philosophers, how from the One, if it is such as we say it is, anything else, whether a multiplicity or a dyad or a number, came into existence, and why it did not on the contrary remain by itself, but such a great multiplicity flowed from it as that which is seen to exist in beings, but which we think it right to refer back to the One'.

${ }^{90}$ Rist, Plotinus, 212. 
or to the conversion and the gazing upon the One there is no being yet. An initial aptitude, what, for instance, Proclus would establish later as essential aptitude

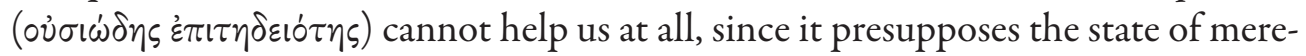
ly being which Plotinus does not seem to acknowledge at this stage. ${ }^{91}$ This is a perplexity I have not managed to solve. It has been very hard to find evidence in the literature on this particular point; It seems that several scholars take this infinitesimal detail in the generation of the second hypostasis rather for granted; or they just feel satisfied with the limited explanatory capacity the form of metaphor possesses. Yet, I would suggest a compromise in a temporal solution. Namely, to assert in a manner of speaking that there is a perfect, infinite aptitude in the One, which transfers simultaneously, and again, in a manner of speaking, to the generated and precisely allows for it becoming Intellect. Similarly, I would think the case of the second procession, from the Intellect to the Soul. Moreover, I would assume that this would be about a kind of 'mechanistic aptitude', and I would collate it with the radiation of light from the sun. That would be something close to what Plotinus suggests later on in the same Ennead V.1:

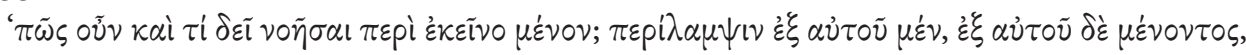

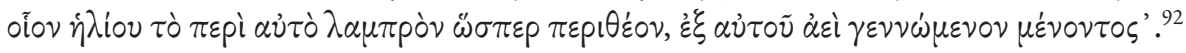

Earlier, I addressed a difficulty that occurs once one wishes to comprehend how and why the emanation mechanism generates entities inferior to their prior hypostasis, starting from the One, and imperfected compared to It, while, at the same time, these entities have a desire to revert to the One and seek perfection. Plotinus persistently addresses the question in a slightly modified manner that reveals a particular consideration of epitédeiotes both as capacity of the intellect for seeing and as prayer $(\varepsilon \dot{v} \chi \varepsilon \sigma \theta \alpha \mathrm{l})$. It is true that elsewhere he has explained emanation by means of the over-excess of perfection of the One. ${ }^{93}$ Yet, one could speculate and - on the basis that the current setting relates to the first procession that comes out of the One and results in the production of the Intellect - one could dare to say that, reasons for the halt of what overflows are either the attractive pow-

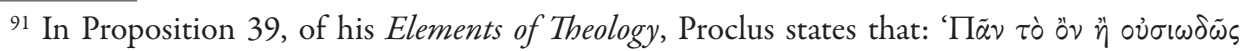

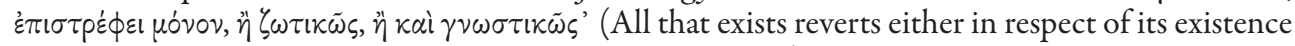
only, or in respect of its life, or by the way of knowledge also), and he explains, further on, that: ' $k \alpha i$

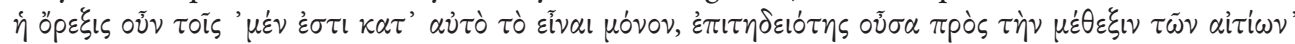
(Some things, accordingly, have appetition in respect of bare existence only, that is a fitness [aptitude] for the participation of their causes). See, Dodds, Proclus, 40-43.

92 Plotinus, Enn. V.1.6, 27-30: 'How did it come to be then, and what are we to think of as surrounding the One in its repose? It must be a radiation from it while it remains unchanged, like the bright light of the sun which, so to speak, runs round it, springing from it continually while it remains unchanged'.

${ }_{93}$ Plotinus, Enn. V.2.1, 7-10. 
er of the One, or -in more psychological terms- the realization that nothing can stand self-sufficiently, except for what is the source of self-sufficiency. A third reason, and a more logical one, would be that no multiplicity whatsoever can stand independently of the One, and this is precisely what Plotinus has in mind in making room for a halt of what proceeds out of It. But Plotinus himself has a different opinion. He does not immediately proceed to offer an easy positivist answer. His answer emerges in the context of the relation of a particular soul, the human soul, with the One and offers a very rich alternative with valuable implications for our understanding of his concept of epitédeiotes. This Plotinian alternative involves prayer. In Ennead V.1 we read:

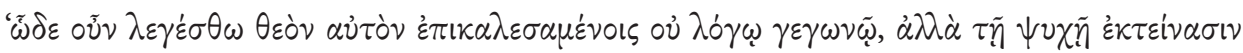

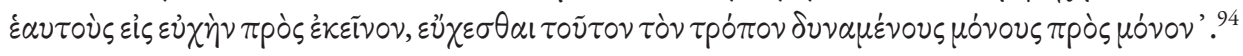

Plotinus conceives of prayer in its highest form; praying in this context is not about a loud repetition of words addressing God, but rather corresponds to this meditation and reflection of the One by a soul that is not distracted by the multiplicity of things. Moreover, Plotinus' notion of prayer in our passage reveals its function in shaping the presuppositions for encountering the divine. It is about the proper preparation that will allow for the soul to attain the mystic vision of the One. As such, prayer is the provider of aptitude for recognizing the omnipresence of the One that Plotinus tries to explain in Ennead VI.5. In fact, the performance of this mystical prayer reveals to man a reality he was previously not aware of: that the One is always turned towards us.

There is a very interesting parallel at this point in the way Plotinus and Gregory of Nyssa approach prayer. One may say - apparently on the condition that many significant differences should be acknowledged, such as the fact that for Plotinus 'there is no question of a conscious turning of the One to the soul',95 that cannot be discussed here - that St. Gregory confirms in his own way what Ploti-

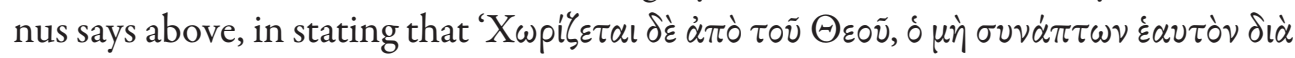
$\tau \tilde{\eta} \varsigma \pi p \circ \sigma \varepsilon v \chi \tilde{\eta} s \tau \tilde{\omega} \Theta \varepsilon \tilde{\omega}$ ' (he who does not unite himself to God by means of prayer distances himself from Him). ${ }^{96}$

Rist beautifully interprets Plotinus' reality of prayer in the following way: 'When a man prays 'alone to the Alone', he has come to recognize that the One is always present and that it is up to himself to look towards him if he wishes. The

${ }^{94}$ Plotinus, Enn. V.1.6, 9-12: 'Let us speak of it in this way, first invoking God himself, not in spoken words, but stretching ourselves out with our soul into prayer to him, able in this way to pray alone to him alone'.

${ }^{95} \mathrm{Ibid}$.

${ }^{96}$ Gregory of Nyssa, De Oratione Dominica 1, PG 44: 1124a; Lucas Francisco Mateo-Seco, "Prayer", in: L.Fr. Mateo-Seco and G. Maspero, Gregory of Nyssa, 643. 
higher prayer, like the lower, is recognition by man of what the universe is like. The One is always turned towards us; in the highest act of prayer we turn again towards him. ${ }^{97}$ This interpretation reveals the eschatological dimension of epitédeiotes in a Plotinian context that anticipates the fulfillment of the expectation uttered in the opening of Ennead V.2:



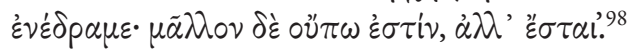

This is perhaps one of the most genuinely and wonderfully Neoplatonically expressed eschatological anticipations, that points - as far as it is attainable to the human intellect - towards an open ontology, the fulfillment of which is expected in the eschata. Plotinian eschatology may be portrayed as that state in which all aptitudes for beings' conversion to the One will be fully translated into perfect actuality, that actuality of the unity of the whole. Doubtless, and given certain fundamental modifications, the motif of the unification of the whole is somewhat common between Plotinus and the Christian fathers, ever since the early Church, which until now unceasingly repeats the request that all become one ( $\left.i v \propto \tilde{\omega} \sigma \nu \nu \varepsilon^{\prime} v\right)$.

\section{Conclusions}

Epitédeiotes denotes a concept of aptitude that is central in Late Antique and Early Christian thought. The concept is explicitly or implicitly enhancing the conceptual apparatus of the Neoplatonists in their enormous efforts a) to conceive of the production of the cosmos from a singular being and principle, b) to grasp how multiplicity shares in unity, c) to analyze the reality of participation in all its dimensionality, d) to specify the communion between the hierarchically differentiated strata of beings, and e) to solve the problem of the bondage of the soul with the body in order for the resort to the divine to become possible. At the same time, the concept is developed by the Church Fathers as a central component of the philosophical articulation of Christian doctrine, which, among other things a) argues for the creation of the cosmos out of nothing, b) argues for the entrance of the maker of the cosmos into it, with the Incarnation of God in the person of Christ, c) investigates the new horizons such an act of incarnation unveils to the mankind, and d) argues for the possibility of deification as the ultimate actualization of the capacity of the human being to become God by grace.

\footnotetext{
${ }^{97}$ Rist, Plotinus, 212.

${ }_{98}$ Plotinus, Enn. V.2.1, 1-3: 'The One is all things and not a single one of them: (for) it is the principle of all things, not all things, but all things have that other kind of transcedent existence; for in a way they do occur in the One; Or rather they are not there yet, but they will be.' It would be worth studying further the reception of this Plotinian passage by the Church fathers: I am very confident that they have regarded it with great empathy.
} 
In Plotinus' original Neoplatonist account aptitude has a central role. It argues for the fact that the ontological diversity observed in the cosmos is not due to the imperfect presence of being. The World Soul is wholly present, without discrimination and limitations in the whole of the particular souls. Plotinus asserts that it is not any deficiency of the third hypostasis that should be blamed for the ontological differentiation among beings. What accounts for difference in the sensible world is the differentiated degree of participation in the Soul. The difference, this diversity, emerges and is governed, so to speak, by the aptitude of particular beings for establishing a share in the -superior to them- source of being. The centrality of the concept is evident by the fact that it pervades the whole of the Plotinian system while it is linked to a wider cluster of terms and concepts. No less, Plotinus seems to be an innovator in the use of the concept of aptitude within Neoplatonism.

I would like to add a final note. One of the contributions of this article was to underline the firm and close relation between Plotinus and Christianity. Much has been written on it and presumably much more is about to come. What would be particularly interesting to see in the future bibliography is scholarly contributions that would challenge the almost commonly established - in the study of the history of philosophy - 'evolutionary' arrow that directs from the Neoplatonist, vertically hierarchized, emanative three-hypostatic All to the Christian, horizontally consubstantial, Trinitarian personal God and His cosmic manifestation through His divine providential, creative, sustaining and redemptive activity that produces being out of nothing and grants it the gift of deification. In other words, it will be very interesting to see further evidence that would challenge the present direction of this arrow in the philosophy of Late Antiquity. ${ }^{99}$

\section{Bibliography}

\section{Primary Texts}

For the works of Plato and Aristotle I have used the editions of $O C T$ and $L C L$.

CD I, Pseudo-Dionysius Areopagita, De Divinis Nominibus, Suchla, Beate Regina (ed.), PTS 33, Berlin: Walter De Gruyter, 1990.

$P G$, J. P. Migne (ed.), vol. 3-4, Paris, 1857.

$P G$, J. P. Migne (ed.), vol. 44, Paris, 1864.

\footnotetext{
${ }^{99}$ I would like to express my gratitude a) to my supervisors of the doctoral research at the Department of Philosophy in the University of Oslo, Torstein Theodor Tollefsen and Eyjólfur Kjalar Emilsson, both for our fruitful discussions and their invaluable advices, b) to Norman Russell for his linguistic suggestions that have improved my text, and c) to the reviewer and to the Editor of the AKROPOLIS Journal of Hellenic Studies for making this publication possible. The author remains accountable for any inadequacies throughout the present piece of work.
} 
PG, J. P. Migne (ed.), vol. 90, Athens, 2009.

Plotinus, Porphyry On Plotinus Ennead I, Armstrong, Arthur Hilary (transl.), LCL 440, Massachusetts: Harvard University Press, 1966.

Plotinus, Enneads II-VII, Armstrong, Arthur Hilary (transl.) LCL 441-445 and 448 Massachusetts: Harvard University Press, 1966-1988.

Proclus, The Elements of Theology, Dodds, E.R. (ed.), Oxford: Clarendon Press, 1963 (1st edition 1933).

\section{Texts and Translations}

Aristotle, The Complete Works of Aristotle. The Revised Oxford Translation, Barnes, Jonathan (ed.), Princeton: Princeton University Press, 1984 (sixth printing with corrections 1995).

Dionysius the Areopagite, Works, Parker, John (transl.), Oxford: James Parker and Co., 1897.

Maximus Confessor, Selected Writings, Berthold, George C. (transl.), CWS, New York: Paulist Press, 1985.

Pseudo-Dionysius, The Complete Works, Colm Luibheid (transl.), CWS, New Jersey: Paulist Press, 1987.

St. Thomas Aquinas, Summa Theologica, Volume I, Fathers of the English Dominican Province (transl.), London: Sheed and Ward, 1981.

\section{Other Works}

Allen, Pauline and Neil, Bronwen (eds.), The Oxford Handbook of Maximus the Confessor, Oxford: Oxford University Press, 2015.

Armstrong, Arthur Hilary, The Architecture of the Intelligible Universe in the Philosophy of Plotinus, An Analytical and Historical Study, Cambridge: Cambridge University Press, 1940.

Armstrong, Arthur Hilary (ed.), The Cambridge History of Later Greek and Medieval Philosophy, Cambridge: Cambridge University Press, 1967.

Armstrong, Arthur Hilary, 'Plotinus', in: A.H. Armstrong (ed.) The Cambridge History of Later Greek and Medieval Philosophy, Cambridge: Cambridge University Press, 193-268, 1967.

Chantraine, Pierre, Dictionnaire Étymologique de la Langue Grecque. Histoire des Mots, Paris: Éditions Klincksieck, 1968.

Cleary, John J. (ed.), Traditions of Platonism, Essays in Honour ofJohn Dillon, Aldershot: Ashgate, 1999.

Cooper, John M. (ed.), Plato Complete Works, Indianapolis: Hackett Publishing Company, 1990.

Dimitrov, Dimitar Y., 'Neoplatonism and Christianity in the East: philosophical and theological challenges for bishops', in: P. Remes and Sv. Slaveva-Griffin (eds.) The Routledge Handbook of Neoplatonism, London: Routledge, 525-540, 2014.

Emilsson, Eyjólfur Kjalar, 'Remarks on the Relation between the One and Intellect in Plotinus', in: J.J. Cleary (ed.) Traditions of Platonism, Essays in Honour of John Dillon, 271-290, 1999.

Emilsson, Eyjólfur Kjalar and Strange, Steven Keith (eds.), Plotinus, Ennead VI.4-5, On the Presence of Being, One and the Same, Everywhere as a Whole, Las Vegas: Parmenides Publishing, 2015.

Emilsson, Eyjólfur Kjalar, Plotinus, Oxford: Routledge, 2017.

Gersh, Stephen, From Iamblichus to Eriugena, An Investigation of the Prehistory and Evolution of the Pseudo-Dionysian Tradition, Leiden: Brill, 1978.

Gerson Lloyd P. (ed.), The Cambridge History of Philosophy in Late Antiquity, Volumes I-II, Cambridge: Cambridge University Press, 2010.

Halfwassen, Jens, 'The Metaphysics of the One', in: P. Remes and Sv. Slaveva-Griffin (eds.) The Routledge Handbook of Neoplatonism, London: Routledge, 182-199, 2014. 
Jaeger, Werner, Paideia. The Ideals of Greek Culture, vol. I (in three volumes), Gilbert Highet (transl.), New York: Oxford University Press, 1965.

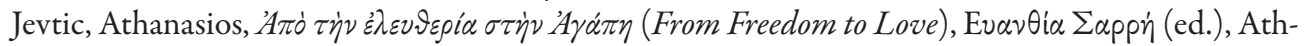
ens: Domos [in Greek], 2012.

Laird, Raymond J., 'Mindset ( $\left.\gamma v \omega^{\prime} \mu \eta\right)$ in John Chrysostom', in: P. Allen, and Br. Neil (eds.) The Oxford Handbook of Maximus the Confessor, Oxford: Oxford University Press, 194-211, 2015.

Lee, Jonathan Scott, 'The Doctrine of Reception According to the Capacity of the Recipient in Ennead VI. 4-5', Dionysius 3, 79-97, 1979.

Lidell, Henry George and Scott, Robert (eds.), A Greek-English Lexicon, New York: Oxford University Press, 1996.

Lossky, Vladimir, The Mystical Theology of the Eastern Church, Crestwood: St. Vladimir's Seminary Press, 1957.

Lossky, Vladimir, The Vision of God, Crestwood: St. Vladimir's Seminary Press, 1973, (first published in 1963).

Maraval, Pierre, 'Biography of Gregory of Nyssa', in: L.Fr. Mateo-Seco and G. Maspero (eds.) The Brill Dictionary of Gregory of Nyssa, Leiden: Brill, 103-116, 2010.

Mateo-Seco, Lucas Francisco and Maspero, Giulio (eds.), The Brill Dictionary of Gregory of Nyssa, VCS, 99, Leiden: Brill, 2010.

Mateo-Seco, Lucas Francisco, 'Prayer', in: L.Fr. Mateo-Seco and G. Maspero (eds.) The Brill Dictionary of Gregory of Nyssa, Leiden: Brill, 639-643, 2010.

Meredith, Anthony, 'Gregory of Nyssa', in: Ll.P. Gerson (ed.) The Cambridge History of Philosophy in Late Antiquity, volumes I-II, Cambridge: Cambridge University Press, 471-481, 2010i.

Meredith, Anthony, 'Neoplatonism', in: L.Fr. Mateo-Seco and G. Maspero (eds.) The Brill Dictionary of Gregory of Nyssa, Leiden: Brill, 531-532, $2010 \mathrm{ii}$.

Moran, Dermot, 'Neoplatonism and Christianity in the West', in: P. Remes and Sv. Slaveva-Griffin (eds.) The Routledge Handbook of Neoplatonism, London: Routledge, 508-524, 2014.

Morrow, Glenn R. and Dillon, John. M., Proclus' Commentary on Plato's Parmenides, Princeton: Princeton University Press, 1987.

Mosshamer, Alden A., 'Evil', in: L.Fr. Mateo-Seco and G. Maspero (eds.) The Brill Dictionary of Gregory of Nyssa, Leiden: Brill, 325-330, 2010.

Mueller-Jourdan, Pascal, 'The Foundation of Origenist Metaphysics', in: P. Allen and Br. Neil (eds.) The Oxford Handbook of Maximus the Confessor, Oxford: Oxford University Press, 149-163, 2015.

Neil, Bronwen, 'Divine Providence and the Gnomic Will before Maximus', in: P. Allen and Br. Neil (eds.) The Oxford Handbook of Maximus the Confessor, Oxford: Oxford University Press, 235249, 2015.

O’ Meara, Dominique, 'The Problem of Omnipresence in Plotinus Ennead VI, 4-5: A Reply', Dionysius 4, 61-73, 1980.

Pavlos, Panagiotis G., 'Aptitude ('E $\pi \imath \uparrow \eta \varepsilon \varepsilon$ ió $\eta \varsigma$ ) and the Foundations of Participation in the Philosophy of Dionysius the Areopagite', Studia Patristica Series, Vol. XCVI - Papers presented at the Seventeenth International Conference on Patristic Studies held in Oxford 2015, M. Vinzent (ed.), Leuven: Peeters, 377-396, 2017.

Pochoshajew, Igor, 'Plotinus', in: L.Fr. Mateo-Seco and G. Maspero (eds.) The Brill Dictionary of Gregory of Nyssa, Leiden: Brill, 629-631, 2010.

Remes, Pauliina and Slaveva-Griffin, Svetla (eds.), The Routledge Handbook of Neoplatonism, London: Routledge, 2014.

Rist, John M., Plotinus: The Road to Reality, Cambridge: Camrbidge University Press, 1967. 
Russell, Norman, The Doctrine of Deification in the Greek Patristic Tradition, Oxford: Oxford University Press, 2006.

Sambursky, Samuel, The Physical World of Late Antiquity, London: Routledge and Kegan Paul, 1962.

Spearritt, Placid, A Philosophical Inquiry into Dionysian Mysticism, Fribourg: University of Fribourg, 1968.

Strange, Steven Keith, 'Plotinus' Account of Participation in Ennead VI.4-5', Journal of the History of Philosophy, 30:4, 479-496, 1992.

Tollefsen, Torstein Theodor, 'Did St. Maximus the Confessor Have a Concept of Participation?', Studia Patristica XXXVII, Papers Presented at the Thirteenth International Conference on Patristic Studies held in Oxford 1999, Cappadocian Writers, Other Greek Writers, M.F. Wiles and E.J. Yarnold (eds.), Leuven: Peeters, 618-625, 2001.

Tollefsen, Torstein Theodor, Activity and Participation in Late Antique and Early Christian Thought, Oxford: Oxford University Press, 2012.

Tollefsen, Torstein Theodor, 'Christocentric Cosmology', in: P. Allen and Br. Neil (eds.) The Oxford Handbook of Maximus the Confessor, Oxford: Oxford University Press, 307-321, 2015.

Turcescu, Lucian, 'Person', in: L.Fr. Mateo-Seco and G. Maspero (eds.) The Brill Dictionary of Gregory of Nyssa, Leiden: Brill, 591-596, 2010. 